

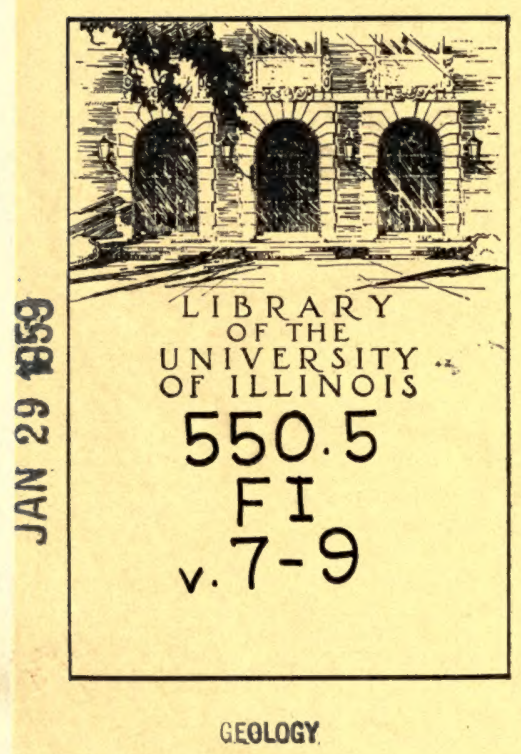

\section{UNIVERSITY OF ILLINOIS LIBRARY AT URBANA-CHAMPAIGN GEOLOGY}


Return this book on or before the Latest Date stamped below. GEOLOGY LIBRARY

University of Illinois Library

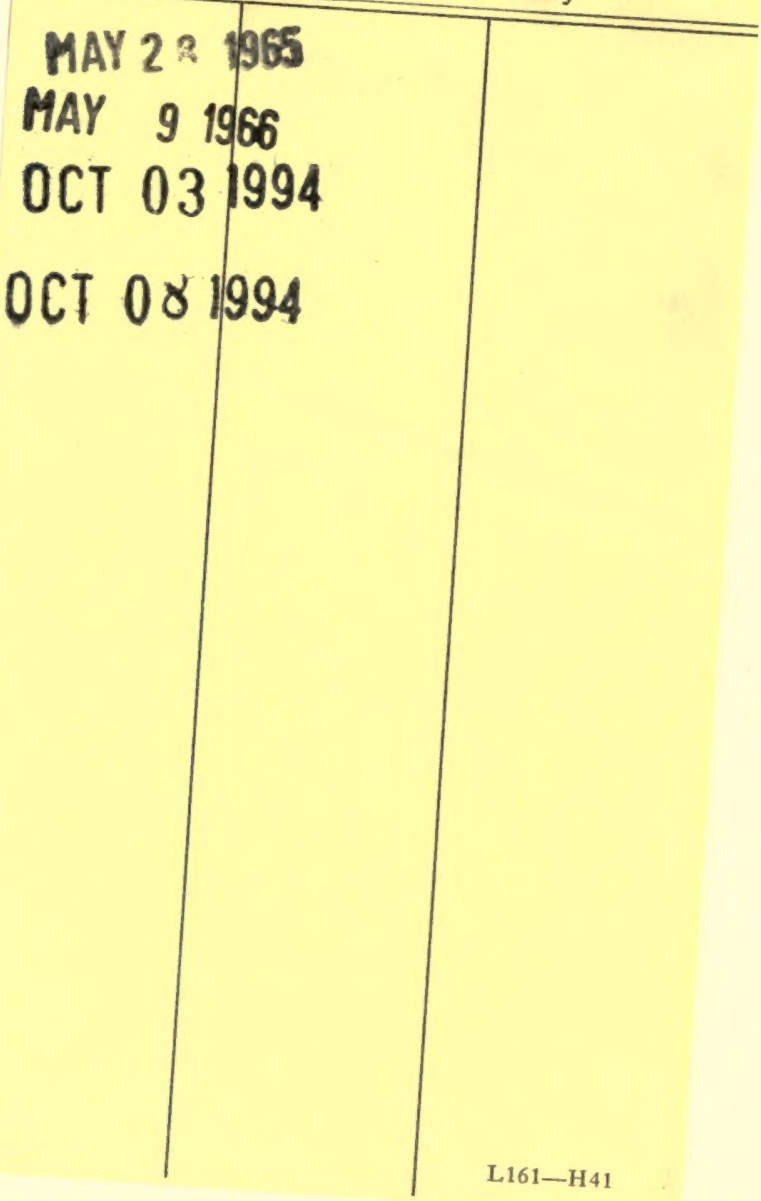







\section{THE APLODONTOIDEA}

BY

PAUL O. MCGREW

ASSISTANT CURATOR, PALEONTOLOGY

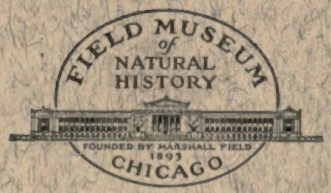

GEOLOGICAL SERIES

FIELD MUSEUM OF NATURAL HISTORY

VOLUME 9, NUMBER 1

DECEMBER 5, 1941

PUBLICATION 510

THE LIBKAKY OF THE

DEC 181941 



\title{
THE APLODONTOIDEA
}

\author{
BY \\ PAUL O. MCGREW \\ ASSISTANT CURATOR, PALEONTOLOGY
}

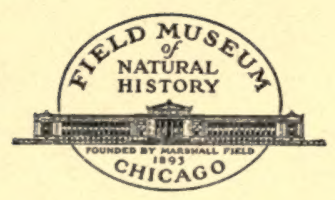

GEOLOGICAL SERIES

FIELD MUSEUM OF NATURAL HISTORY

VOLUME 9, NUMBER 1

DECEMBER 5, 1941

PUBLICATION 510

THE LIBRARY OF THE

DEC 181941 
PRINTED IN THE UNITED STATES OF AMERICA BY FIELD MUSEUM PRESS 


\section{THE APLODONTOIDEA}

BY PAUL O. MCGREW

Among the specimens collected in 1940 by a Field Museum expedition are two aplodontoid rodents from the Rosebud beds of South Dakota. These specimens are of unusual interest because they practically close the structural and time gap that has separated the John Day Meniscomys from the late Miocene and early Pliocene mylagaulids. Although the discovery of Mylagaulodon (Sinclair, 1903) had partially filled this gap, Matthew's conclusions, first, that the genus had no relationship to Mylagaulus and, second, that its type was a young individual of Mylagaulus, tended to mask the true significance of Sinclair's specimen. In general, the discovery of the new specimens herein described supports the widely accepted conclusions as to the relationship and ancestry of the Mylagaulidae; namely, that the family was descended from Meniscomys or a closely related form, and should be included in the Aplodontoidea.

I am deeply indebted to the authorities of the American Museum of Natural History, especially to the late Walter Granger, for permitting me to study important types, and to Mr. J. LeRoy Kay and Dr. John Clark of the Carnegie Museum for permission to study specimens in that institution. Drs. R. A. Stirton and C. L. Camp of the University of California have facilitated this study by loaning me specimens in their collections. I also wish to thank Mr. and Mrs. Harry Tylee of Wounded Knee, South Dakota, for the assistance and hospitality they provided our field party while collecting the new specimens described herein. Figure 1 was drawn by $\mathrm{Mr}$. John J. Janecek, the remainder by Mr. John Conrad Hansen.

\section{PREVIOUS WORK}

Little confusion has existed regarding the origin and evolution of the Aplodontidae. Cope (1883 and 1884) recognized the resemblance between Meniscomys and Aplodontia and although he realized that the two were related, he referred Meniscomys to the Sciuridae. With the description of Liodontia (Furlong, 1910), the long gap between the John Day Meniscomys and the recent Aplodontia was partially closed by an intermediate form. It was Furlong's opinion that Liodontia was close to the ancestry of Aplodontia and a deriva- 
tive of Meniscomys. These conclusions were substantiated by the work of Matthew (1904, 1910, 1924), Merriam (1916), Stock (1935), Gazin (1932), and Wilson (1937a). ${ }^{1}$

As regards the Mylagaulidae there has been no such agreement. In his description of Mylagaulus sesquipedalis and Mylagaulus monodon, Cope $(1878,1881,1883)$ compared the genus with the castorids and felt that it might bear some relationship to Hystrix. Riggs (1899) was the first to recognize a similarity between Mylagaulus and Meniscomys and he regarded the latter as nearly ancestral to Mesogaulus and Mylagaulus, basing his opinion on the lake pattern of the lower molars. In 1901 Matthew stated his disagreement with Riggs and considered Mylagaulus to be "related to the Sciuridae but not especially to any known member of the family." The following year the same author noted a resemblance between the skulls of Ceratogaulus and Aplodontia, but felt that the extreme difference in the teeth and the presence of horns in the former ruled out any possibility of relationship. In 1903 Sinclair described Mylagaulodon from the John Day beds and immediately recognized its position as intermediate between Meniscomys hippodus and Mylagaulus. Although this form now appears to have been properly interpreted by Sinclair, Matthew (1904) dismissed it with the following statement: “The genus Mylagaulodon Sinclair appears to be related to Meniscomys and Haplodontia, but we are unable to trace any relationship to Mylagaulus, whose teeth in our opinion are derived from a Castorid or Histricomorph pattern with quadrate $\mathrm{P}^{4}$ and no $\mathrm{P}^{3}$. Meniscomys, Mylagaulodon and Haplodontia have, like the Sciuridae, a triangular $\mathrm{P}^{4}$, and $\mathrm{P}^{3}$ very persistent though small." After studying the skeleton of Epigaulus hatcheri, Gidley (1907) reached the following conclusions concerning the relationships of the Mylagaulidae: "It seems evident... that while this extinct group of highly specialized rodents apparently has some remote affinities to the Castoridae and a somewhat nearer relationship to the Sciuridae, as pointed out by Matthew, the family has a far greater number of characters in common with the Aplodontidae, and shows besides some striking resemblances of general proportions to some of the Asiatic forms of the Spalacidae. The resemblance to the latter family, however, seems to be due more to modifications of the skeleton for a similar special adaptation to burrowing habits than to any real relationship." In 1910 Matthew came a little closer

${ }^{1}$ Wilson pointed out certain characters indicating that Liodontia was not on the direct line of descent but he agreed that it was roughly intermediate between Allomys and Aplodontia. 
to the views of Riggs (1899) and Sinclair (1903) by placing both the Mylagaulidae and the Aplodontidae in the superfamily Aplodontoidea. Miller and Gidley (1918) agreed that a relationship existed between Meniscomys and Aplodontia but placed them in different families. The Mylagaulidae, they believed, had a fundamentally different type of tooth structure "based on an underlying quadritubercular structure, the hypocone always entering into the essential mechanical scheme of the crown," whereas the teeth of the Allomyidae and the Aplodontidae were based on an "underlying tritubercular structure." Mylagaulodon they regarded as an "allomyid." The discovery of a good series of mylagaulids convinced Matthew (1924) that Riggs was correct - that the mylagaulids were an offshoot from the Meniscomys stock. Subsequently Gazin (1932), Stock (1935), and Wilson (1937a) have supported this view. Matthew (1924) also arrived at the conclusion that Sinclair's Mylagaulodon represented a young individual of Mylagaulus, bearing milk teeth, and that Mylagaulodon was therefore invalid. $\mathrm{He}$ was followed in this by Stock (1935), who made the last important contribution to our knowledge of the group with a description of the primitive Eohaplomys, a form from the Sespe Eocene which he regarded as intermediate between Allomys (also Meniscomys) and Paramys. ${ }^{1}$

\section{DESCRIPTION OF NEW MATERIAL}

Promylagaulus gen. nov.

Genotype.-Promylagaulus riggsi sp. nov.

Distribution.--Early Miocene, South Dakota.

Diagnosis.-Facial region of skull similar to that of Meniscomys; dentition $\mathrm{I}_{1}^{\frac{1}{1}}, \mathrm{P}_{\frac{2}{1}}, \mathrm{M}_{\frac{3}{3}}$; cheek teeth rooted; hypsodont but less so than those of Mylagaulodon; $\mathrm{P}^{3}$ small and conical as in Aplodontia; $\mathrm{P}^{4}$ approximately twice as large as $\mathrm{M}^{1}$, with mesostyle and four lakes in worn tooth. Molars with single lake when worn.

\section{Promylagaulus riggsi ${ }^{2}$ sp. nov.}

Holotype.-F.M. No. P26256, facial region of skull with incisors and complete cheek-tooth series. Found by Henry Horback.

${ }^{1}$ Since this paper went to press Cook and Gregory (1941) have redefined Mesogaulus and concluded that it is intermediate between Mylagaulodon and Mylagaulus. Mesogaulus, then, includes those species which are referred to in this paper as "primitive species of Mylagaulus."

${ }^{2}$ In honor of Mr. Elmer S. Riggs, Curator of Paleontology in Field Museum of Natural History, who first recognized the relationship between the Mylagaulidae and Meniscomys. 
Locality and horizon.-Four miles south of Porcupine, South Dakota; top of -lower Rosebud beds.

Diagnosis.-Only known species of the genus. For measurements see page 28.

Description.-In the portion of the skull preserved, the part anterior to the parietals, there is a fundamental similarity to Menis-
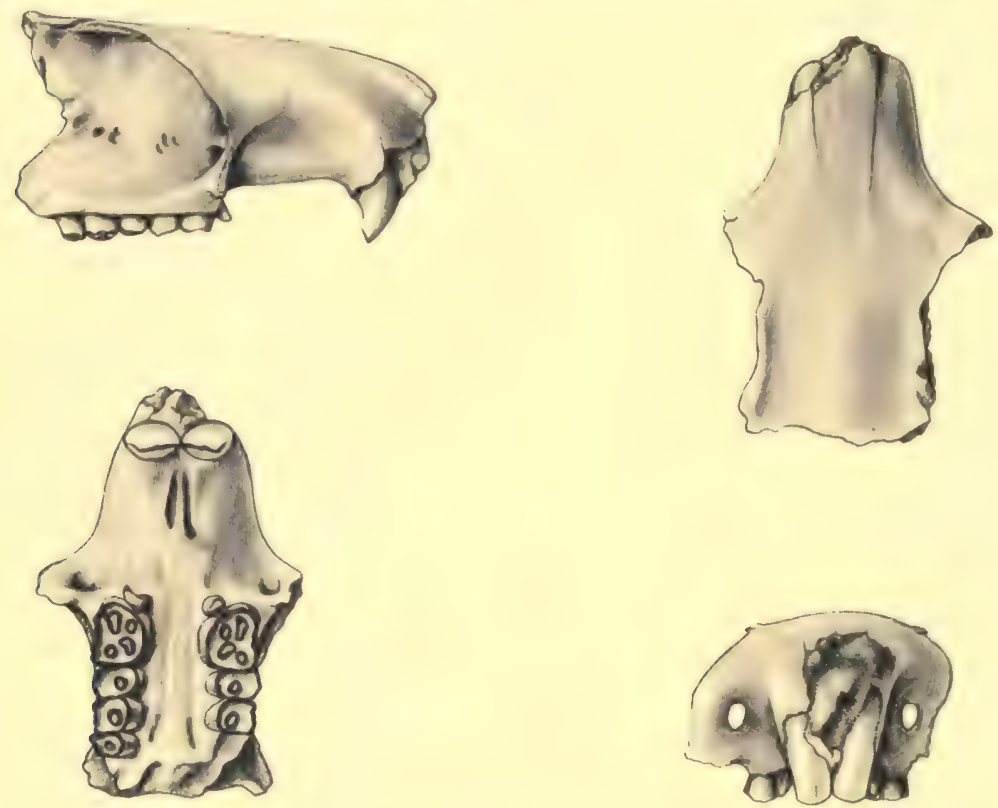

FIG. 1. Promylagaulus riggsi gen. et sp. nov. F.M. No. P26256. Partial skull; dorsal, ventral, lateral, and anterior views. $\times 2$.

comys combined with certain resemblances to Aplodontia and Mylagaulus. The few discernible differences from Meniscomys in skull structure are slight and proportional but approach in some degree the characters of Mylagaulus. The nasals are rather narrower than those of Aplodontia and extend more posteriorly, although not so far as in Mylagaulus. As in the living genus, the tips of the nasals, as well as the upper portion of the premaxillaries, pinch in anteriorly. The skull is not so much constricted between the orbits as that of Aplodontia. The dorsal rims of the orbits are so damaged that it is impossible to determine whether or not postorbital processes were present. The fact that the skull is relatively wide in this region may indicate that there were incipient processes. 
The infraorbital foramen is the same relative size as that of Mylagaulus, and somewhat smaller than that of Aplodontia. The position of the foramen, as in Aplodontia and Mylagaulus, is above and external to $\mathrm{P}^{\underline{3}}$ ( $\mathrm{dP}^{3}$ in Mylagaulus). In Promylagaulus, however, it is relatively higher than in Aplodontia and lower than in Mylagaulus. The higher position in the Mylagaulidae apparently
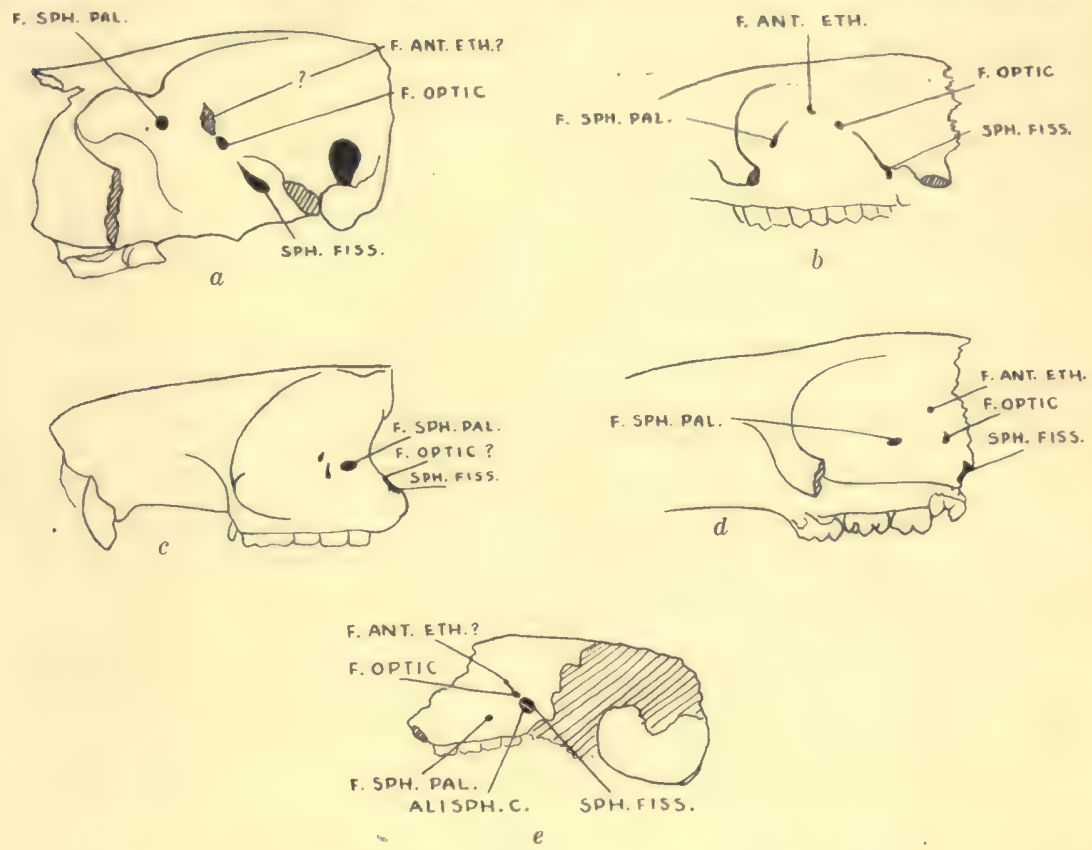

FIG. 2. Cranial foramina of a, Mylagaulus; b, Aplodontia; c, Promylagaulus; d, Ischyromys; and e, Allomys.

may be correlated with a progressive deepening of the maxillary brought about by the increase in size and length of $\mathrm{P}^{4}$.

The nasolacrimal foramen, lying immediately above the posterior opening of the infraorbital foramen, is large and does not differ significantly from that of other aplodontoids.

The sphenopalatine foramen is more posterior in position than in other aplodontoids examined but is otherwise typical.

Anterior to the sphenopalatine are two small foramina. In Mylagaulus one foramen occupies the same position but none is present in Aplodontia. Such foramina apparently are constant only in the Mylagaulidae and it would seem that they are nutrient, supplying the enlarged $\mathrm{P}^{4}$. 
Unfortunately, the skull is broken away posterior to the optic foramen and sphenoidal fissure. A rounded portion of surface bone where the skull is broken seems to indicate the presence of these openings in much the same position as in Mylagaulus, but this is not certain.

The cranial foramina of Ischyromys, ${ }^{1}$ Allomys, Promylagaulus, Mylagaulus, and Aplodontia show a distinét similarity of patternone which differs from that of other rodent groups. The similarity of these genera extends to Ischyromys (a skull of Paramys was not available), a fact that is in agreement with the primitive condition retained throughout the suborder.

The incisors of Promylagaulus are broader relatively than those of Aplodontia but not so broad as those of Mylagaulus. They are slightly convex anteriorly, as in the living genus.

$\mathrm{P}^{\underline{3}}$ is very small and conical, as in Aplodontia and as $\mathrm{dP}^{3}$ of Mylagaulus. It differs from that of Allomys and Meniscomys in that it is more reduced and more perfectly conical in form.

$\mathrm{P}^{4}$ is roughly quadrangular with an antero-external projection extending forward. It is nearly intermediate in form between that of Meniscomys, which is triangular, and that of Mylagaulus, which is oval. The enamel of the external border forms a low inverted $\mathrm{W}$, the two projections being the mesostyle and an external projection from the parastyle. The tooth is relatively much larger than that of Meniscomys and is more hypsodont but much less so than that of Mylagaulodon and Mylagaulus. The cusps of $\mathrm{P}^{4}$ may rather confidently be homologized with those of Meniscomys and Aplodontia. In an unworn condition the tooth probably would have resembled closely that of Meniscomys in cusp pattern. Four lakes extend deeply into the crown and they too can be homologized with depressions in $\mathrm{P}^{4}$ of Meniscomys and Aplodontia and with lakes in $\mathrm{P}^{4}$ of Mylagaulodon and Mylagaulus.

The molars of Promylagaulus are considerably reduced but not to the same extent as in Mylagaulus. Externally, only a trace of the mesostyle remains; the style was doubtless more prominent in less worn teeth. $\mathrm{M}^{\underline{1}} \underline{\underline{2}}$ are approximately square in outline and of nearly equal size. $\mathrm{M} 1 \mathbf{1}$ is somewhat more compressed anteroposteriorly than $\mathrm{M}^{2}$, a step toward Mylagaulus. $\mathrm{M}^{3}$ is smaller than the other teeth of the series and nearly round. Each molar has but a single lake situated posterior to and slightly inside the center

${ }^{1}$ Because no figure showing the foramina was offered by Wood (1937) in his discussion of the cranial foramina of Ischyromys I have been unable to follow his interpretation. In this work the terminology of Hill (1935) is followed. 
of the tooth. To which depression in the tooth of Meniscomys this lake is homologous cannot be determined until unworn upper molars of Promylagaulus are available.

Matthew (1904) has recorded a portion of a lower jaw from the Rosebud beds of South Dakota which he believed to represent

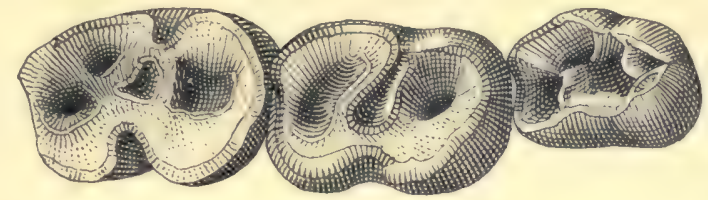

FIg. 3. Promylagaulus cf. riggsi. A.M. No. 10824. Left $\mathbf{M}_{\bar{I}-\overline{3}}$; crown view. $\times 10$.

a species of Meniscomys close to hippodus. Examination of this specimen convinces me that it is not referable to Meniscomys, but is a lower jaw of Promylagaulus, probably of P. riggsi. Although the molars are as small as those of Meniscomys they are set in a jaw that is much larger than any known specimen of the John Day genus. The teeth are more hypsodont than those of Meniscomys, and show an incipient Mylagaulus pattern. Although $\mathrm{P}^{\underline{4}}$ is missing from the specimen, its alveolus indicates that it was enlarged. The ascending ramus begins outside of $\mathrm{M}=$, much farther forward than in Meniscomys, and more nearly in the position seen in Mylagaulus.

Mylagaulodon ef. angulatus Sinclair.

In the upper Rosebud beds of South Dakota, near Porcupine Butte, we were fortunate in finding a single $\mathrm{P} \underline{\mathrm{s}}$ which certainly

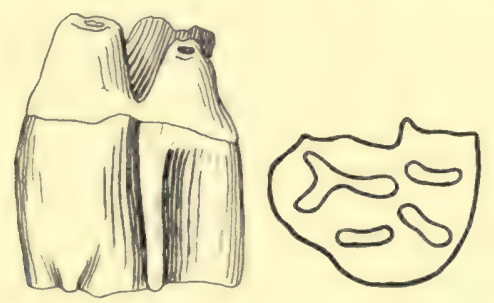

Fig. 4. Mylagaulodon cf. angulatus. F.M. No. P26266. P4; lateral and crown views. $\times 4$.

represents Mylagaulodon. This tooth may be of a species distinct from the John Day specimen but no character unaccounted for by difference in wear can be found to distinguish it. The Rosebud speci- 
men establishes Mylagaulodon as a valid genus and verifies Sinclair's conclusions as to its relationships. $\mathrm{P}^{ \pm}$is strongly hypsodont but has two external and one internal root. At the stage of wear reached by this specimen two external styles are present. The posterior one, the mesostyle, is prominent and extends to the base of the crown. The anterior one is low and would disappear with a little more wear. In general form, the tooth is much like that of Promylagaulus, being roughly quadrangular with an antero-external projection. As in Promylagaulus, the lakes are four in number, but each is considerably longer than in that form. The antero-external lake

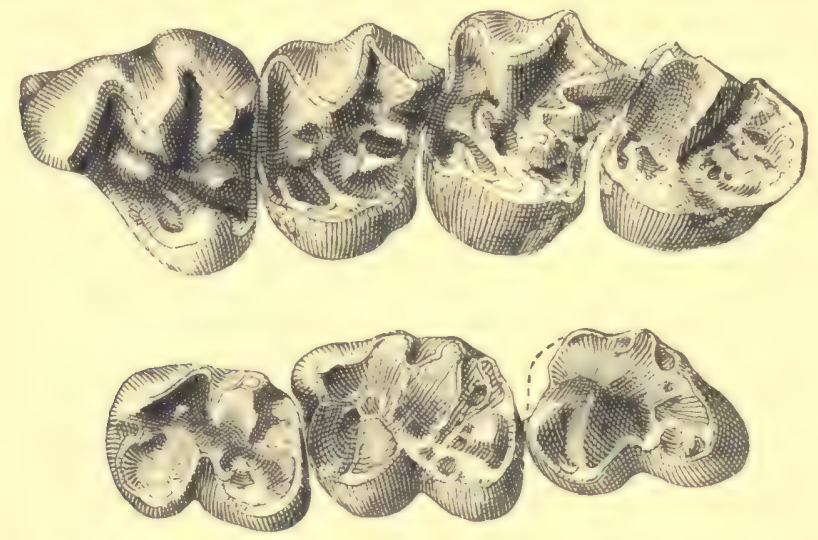

Fig. 5. Allomys cavatus. A.M. No. 6988. Type. Left $\mathrm{P}^{4}-\mathrm{M}^{3}$, right $\mathrm{M}^{1-3}$; crown views. $\times 10$.

branches anteriorly, one prong extending antero-externally, the other antero-internally. This lake is forked in all the later mylagaulids examined, and is suggested in Promylagaulus by a slight widening of the lake anteriorly. The two external lakes are elongated and almost meet near the center of the tooth. The postero-internal lake is oblique.

There can be no doubt that this tooth is a permanent premolar and not, as Matthew supposed, a member of the deciduous series. The roots bend together at the base and do not spread outward for the reception of the crown of a replacing tooth. Also, the degree of hypsodonty attained seems altogether too great for a milk tooth.

\section{Allomys and Meniscomys}

In 1884 Cope recognized four species of Meniscomys: hippodus, liolophus, cavatus, and nitens. The last was described by Marsh 
in 1877 as the genotype of Allomys. Cope believed that the two genera were synonymous but attempted to justify his name, Meniscomys, by the brevity of the description given by Marsh, even though Allomys nitens was adequately figured. Allomys, of course, is valid with nitens as the genotype. The species liolophus was removed from Allomys by Miller and Gidley (1918) and made the type of Haplomys because of its more brachydont and generally more primitive dentition.

After examining Cope's specimens of hippodus, cavatus, and nitens I am convinced that further separation is necessary. Fortu-
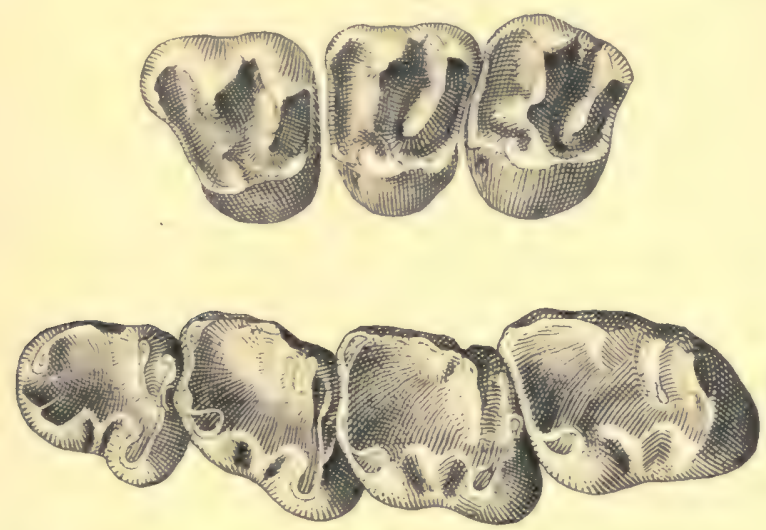

FIG. 6. Prasciurus ef. relictus. F.M. No. P25813, $\mathrm{P}^{\mathbf{1}}-\mathrm{M}^{2}$; and F.M. No. P25815, $\mathrm{P}_{\overline{4}}-\mathrm{M}_{3} \cdot \times 10$.

nately, it is hippodus, which was Cope's type of Meniscomys, that is generically distinct from the other two species, hence the original name may be retained. Allomys cavatus and nitens are very similar and may well represent the same species.

\section{Allomys Marsh 1877}

Genotype.-Allomys nitens.

Known species.-Nitens and cavatus.

Distribution.--John Day formation, Oregon. Distribution within the John Day unknown.

Diagnosis.-Cheek teeth lower crowned than those of Meniscomys; upper molars with high paramere, W-shaped ectoloph; metaloph and protoloph not well developed; protoloph complete, metaloph incomplete; protoloph not connected with anterior cingulum or 
metaloph; hypocone distinct; basins of teeth not enclosed; lower molars basined; metaconid high and connected with protoconid by strong anterior cingulum; posterior cingulum extending inward from hypoconid, but not connecting with entoconid; hypoconulid present; entoconid with projection running to center of tooth (=hypoconulid I of Prosciurus); small mesoconid present; entoconid separated from metastylid and from posterior cingulum by shallow valleys; central basin complicated by numerous shallow pits, or lakes.

\section{Meniscomys Cope 1878}

\section{Genotype.-Meniscomys hippodus. ${ }^{1}$}

\section{Distribution.-John Day formation, Oregon.}

Diagnosis.-Cheek teeth high crowned; upper molars with complete protoloph; protoconule large, connected with protoloph only by posterior edge, and extending to anterior cingulum; metaloph extending between metaconule and anterior base of metacone; metaconule connecting with protoloph and with posterior border of tooth; mesostyle constricted, crown with five well-defined lakes; no hypocone; lower cheek teeth not basined, completely lophodont, metastylid separated from metaconid by deep valley; entoconid and posterior cingulum completely united; molars with three lakes in antero-posterior row.

Discussion.-Allomys, as defined above, combines the characters of Meniscomys and Prosciurus. The complete protoloph, incomplete metaloph, presence of a hypocone, double metaconules and a mesoconid, separation of posterior cingulum from entoconid and the primitive-basined lower cheek teeth, are characters shared by Prosciurus, whereas the elevated paramere, with its crescentic paracone and metacone, and W-shaped ectoloph are characters of Meniscomys. The combination of characters in Meniscomys indicates affinities with Liodontia and Aplodontia and also with the mylagaulids. Allomys seems not to be related to any later types. The fact that the upper molariform teeth of Eohaplomys have a rather well-formed hypocone would indicate, but not prove, that the presence of that cusp is primitive. The variability of the hypocone in Prosciurus, a probable relative, suggests that the structure might readily

1 Riggs (1899) recognized hippodus as generically distinct from the other species referred to Meniscomys and Allomys and placed the species in a new genus Protogaulus. He seems to have been correct in regarding the species as generically distinct but because hippodus is the genotypic species of Meniscomys this original term must stand. 
be lost. If this is true the hypocone of the Aplodontidae was secondarily lost. The more unlikely alternative is that the absence of a hypocone was the primitive condition. This would require independent origin of Allomys and Meniscomys and more parallelism than is probable.

Meniscomys and Allomys, then, represent two related branches of the aplodontid stock, the two running parallel in the development of the paramere, but the former being much more progressive in the lengthening of the crown and development of an advanced tooth pattern.

The primitive condition and late appearance of Haplomys makes it probable that the genus is more closely related to Allomys than to Meniscomys.

\section{EVOLUTION OF APLODONTID DENTITION}

It is certain that the genera Eohaplomys, Meniscomys, Liodontia, and Aplodontia do not represent a direct line of descent. With the exception of a hypocone on the upper molars of Eohaplomys the general structure of this genus probably approaches the primitive condition for the Meniscomys line. The same may be said of Prosciurus which in many respects is more primitive than Eohaplomys. The dentitions of these genera do display a structurally progressive series, however, and from them may be learned the changes that took place between the early ancestors and Aplodontia.

$\mathrm{P}^{\underline{4}}$ of Eohaplomys is brachydont and bears distinct, rounded cusps. Externally three cusps are present: the parastyle, paracone, and metacone. The proto- and metaconules are well developed as is the protocone. There are five incompletely enclosed basins: antero- and postero-external, antero- and postero-internal and transverse median. The last is bounded anteriorly by the paracone and protoconule and posteriorly by the metacone and metaconule. The remainder are bounded by adjacent cusps and low cingula. Two rather low and rounded external styles are present; the mesostyle between the para- and metacones and one between the parastylar cusp and the paracone.

In the position of cusps and basins, $\mathrm{P}^{\underline{4}}$ of Meniscomys is very like that of Eohaplomys. The tooth is distinctly higher and the styles are more prominent. The ridges, which are incipient in Eohaplomys, are elevated so that the cusps are less distinct and the basins more completely enclosed. No hypocone is present in Meniscomys. 

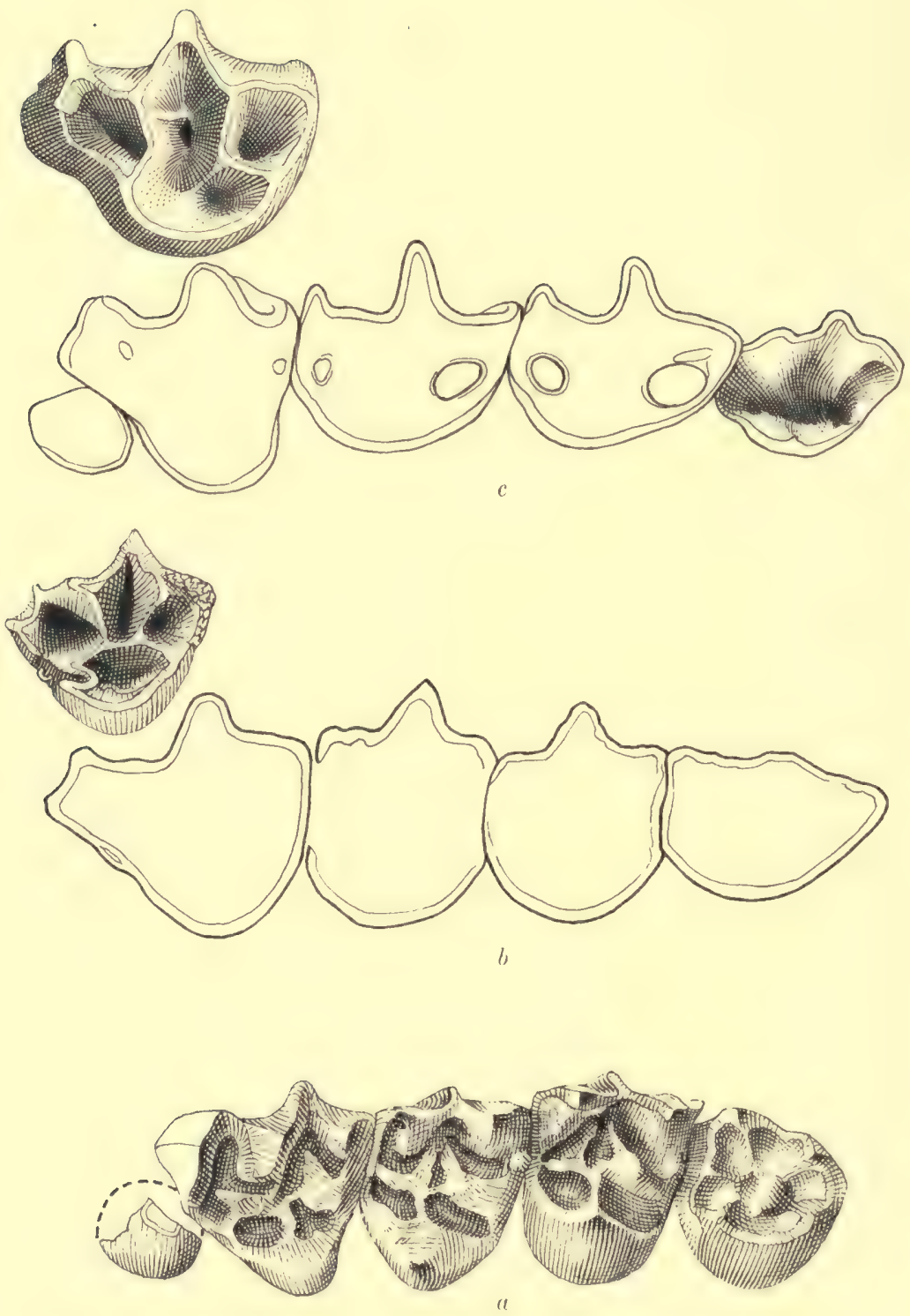

FIG. 7. Upper cheek teeth. a, Meniscomys hippodus, A.M. No. $6965 ; \times 10$. b, Liodontia alexandrae, Univ. Calif. No. $31066 ; \times 10$. c, Aplodontia rufa F.M. No. $41386 ; \times 1$. Insets are unworn $\mathrm{P}^{4}$ of Liodontia $(\times 10)$ and Aplodontia $(\times 10)$. 

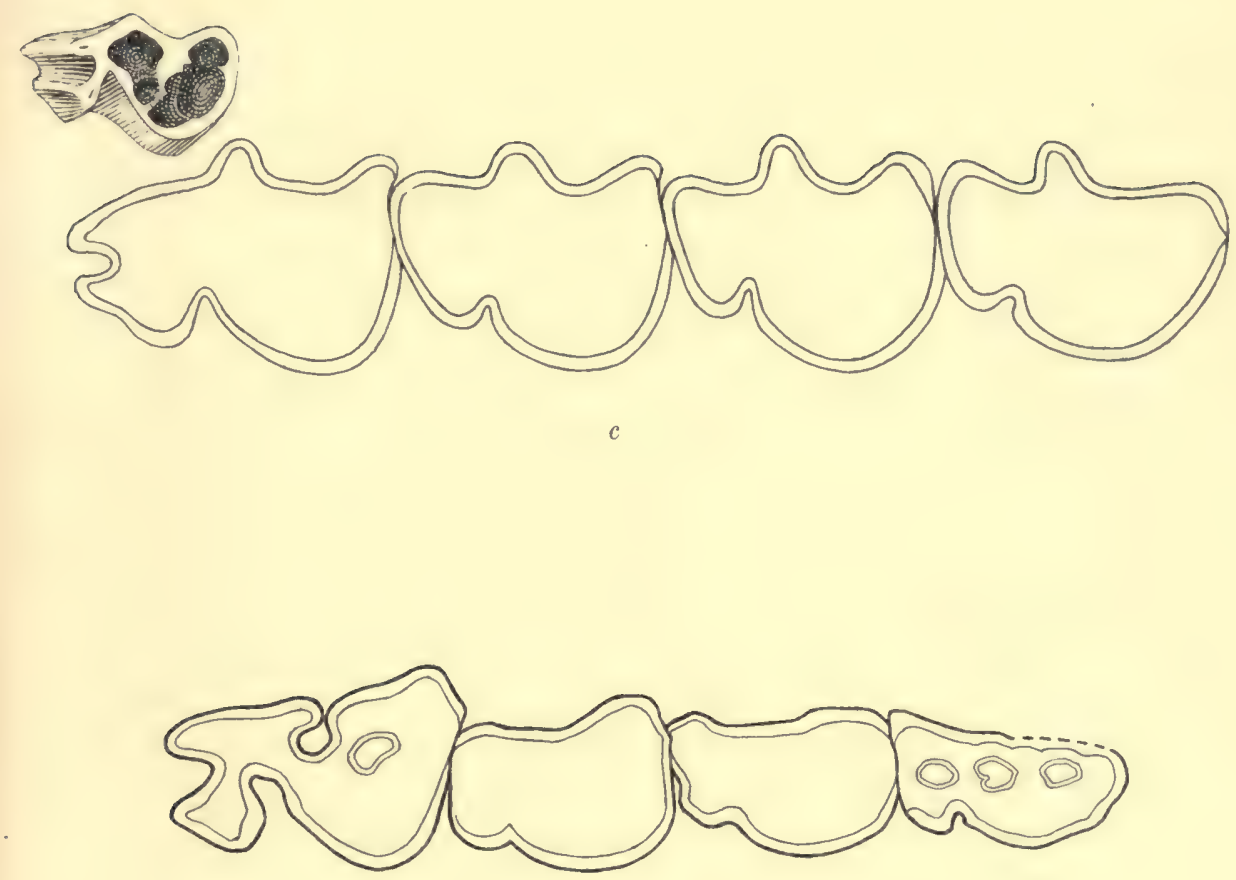

$b$

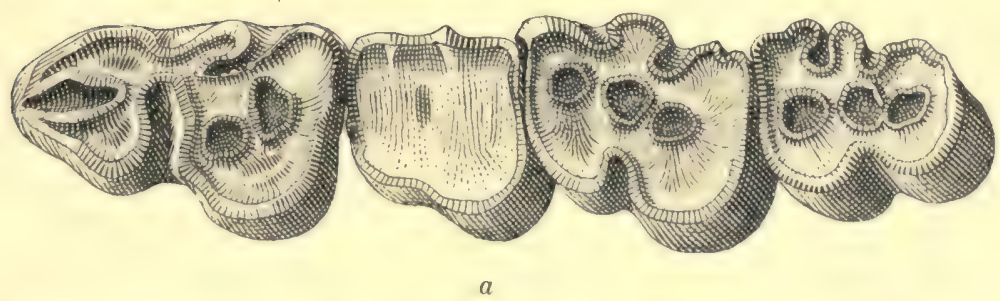

FIG. 8. Lower cheek teeth. a, Meniscomys hippodus, A.M. No. $6964 ; \times 10$. b, Liodontia alexandrae, Univ. Calif. No. $11864 ; \times 10$. c, Aplodontia rufa, F.M. No. 41386. Inset is unworn $\mathrm{P}_{4}$ of Aplodontia. 
Unfortunately no intermediate form between Meniscomys and Liodontia is known. However, the unworn $\mathrm{P}$ s of the latter genus displays a pattern that is amazingly like that of Meniscomys. The same progressive trends by which Meniscomys is advanced over Eohaplomys are carried further in Liodontia. $\mathrm{P}^{ \pm}$is very high-crowned and rootless (at least in little-worn teeth). The cusps and basins are located as in Meniscomys. The cusps are hardly individual units, however, as the connecting ridges are elevated to the height of the cusps themselves. The styles are somewhat more prominent than those of Meniscomys and are more constricted. The anterointernal lake is opened anteriorly by the reduction of the cingular ridge that bounds it. The antero- and postero-external lakes are deepest and (as in Aplodontia) are the last to disappear with wear.

$\mathrm{P}^{4}$ of Aplodontia does not differ greatly from that of Liodontia, but the small differences that do exist are significant. In the living genus the wall between the transverse-median and the posterointernal basins has been lost. The antero-internal basin too has completely disappeared through the loss of the bounding anterointernal cingular ridge. Thus $\mathrm{P}^{\underline{4}}$ of Aplodontia has only three completely enclosed lakes; the transverse-median plus the posterointernal, and the two external ones. By the loss of the anterointernal cingulum the protoconule is brought to the margin of the tooth. The fact that Liodontia approaches Aplodontia in the incipient loss of lakes indicates that the condition represented in the Tertiary genus was a step also attained in the development of the Aplodontia pattern, in spite of the probability that the genera are not on the same direct line.

In general the evolutionary course followed by the upper molars was much like that of $\mathrm{P}^{\underline{4}}$. The basic structure of the molars differs from that of $\mathrm{P}^{\underline{4}}$ in the absence of a cuspate parastyle. In the primitive members of the group there are five lakes, as in $\mathrm{P} \underline{4}$, bounded similarly by cingular ridges and ridges between cusps. There is a strong mesostyle and a much weaker parastylar column. As with $\mathrm{P}^{4}$ the principal progressive change is in increased hypsodonty. There is also a progressive tendency toward transverse constriction of the individual teeth, more so in the posterior than in the anterior molars. The transverse-median lake exists throughout the series and is present with little modification in Aplodontia. The two anterior and two posterior lakes are brought progressively closer together by constriction of the teeth and in Aplodontia these lakes are either united or separated by a thin wall. The depth of the 
lakes does not increase as the teeth become more hypsodont; thus they disappear very early in the life of the individuals.

The lower molars of Aplodontia differ from those of Liodontia in two principal characters. There is less reduction of the protoconid (hence also of the fold between protoconid and hypoconid). Of perhaps more significance is the presence of a prominent internal, median style which does not occur (or only on slightly worn teeth) in Liodontia. ${ }^{1}$ In slightly, and only moderately worn teeth the metaconid and entoconid also project internally which, with the median style, makes three sharp angles on the internal border of the molars. It is probable that the absence of these styles in Liodontia represents the primitive condition and that in its development Aplodontia went through the stage represented by Liodontia, at least in this character. The further reduction of the protoconid in Liodontia seems to be a condition more specialized than that found in Aplodontia and for this reason the Tertiary genus can hardly be ancestral to the latter.

The greatest change in the lower cheek teeth from Eohaplomys to Aplodontia is, as in the uppers, in progressive hypsodonty. $\mathrm{P}_{\overline{4}}$ of Meniscomys hippodus is rather elongated antero-posteriorly. Anteriorly, a deep re-entrant is formed between spurs extending forward from the metaconid and protoconid. Posterior to the metaconid is a metastylid which projects postero-internally. On either side of the metastylid is a re-entrant valley: the anterior one, rather shallow, between the metaconid and metastylid and the posterior one, much deeper, between the metastylid and entoconid. The protoconid is separated from the hypoconid (and trigonid from talonid) by a deep valley extending two-thirds of the way across the tooth. In the talonid are two isolated lakes.

Except in its much more hypsodont condition, $\mathrm{P}_{\overline{4}}$ of Liodontia does not differ greatly from $\mathrm{P}_{4}$ of Meniscomys. The anterior reentrant is present but is not as deep as in Meniscomys. The anterointernal re-entrant is reduced so that there is only a slight concavity anterior to the metastylid. The postero-internal re-entrant is pinched off by a forward expansion of the entoconid, forming a lake which is open internally in unworn teeth. One lake is present in the talonid in a moderately worn specimen but two were probably present in a less worn tooth. The trigonid is somewhat broader than that of Meniscomys.

${ }_{1}$ Though usually referred to as the mesostylid this style is actually modified from the cusp I have interpreted as the metastylid. Whether it should be called mesostylid or metastylid is of no great importance. 
The only important change in $\mathrm{P}_{\overline{4}}$ between Liodontia and Aplodontia is the complete isolation in the latter of the main internal re-entrant. Apparently the wall between the two talonid lakes has broken down so that the entire talonid is occupied by a single large basin. In an unworn $\mathrm{P}_{\overline{4}}$ of Aplodontia a slight enamel ridge partially dividing the basin into two lakes probably represents a remnant of this wall. These lakes, of course, disappear with slight wear.

The lower molars of Meniscomys are based on the primitive tribosphenic structure. The paraconid is lost. Of the four original cusps remaining (protoconid, metaconid, hypoconid, and entoconid), the metaconid is the highest. It is internal and slightly anterior to the protoconid. Behind the metaconid, and connected with it by a ridge, is a metastylid of the same size and height as the hypoconid and entoconid. A spur runs antero-internally from the rather large, $\mathrm{V}$-shaped protoconid to the anterior base of the metaconid. A second ridge runs internally from the protoconid to the center of the tooth, then turns postero-internally to join the metastylid. Between and external to the metastylid and metaconid is a deep depression which connects with a somewhat shallower fossa between the protoconid and metaconid. The hypoconid is more U-shaped than the protoconid. Between these two cusps is a deep fold extending nearly to the center of the tooth. A ridge extends antero-internally from the hypoconid and joins the crest connecting the protoconid and metastylid. From the middle of this ridge a branch extends to a slight swelling on the posterior branch of the tooth. This swelling probably represents the hypoconulid. Between the last-mentioned ridge and the hypoconid is a lake. The entoconid, connected by a posterior ridge to the hypoconulid and hypoconid, is well separated from the metastylid by a deep internal re-entrant which divides the talonid from the trigonid. A spur runs antero-externally from the entoconid to connect with a ridge between the hypoconid and the posterior border of the trigonid.

Unfortunately, the detailed character of the lower molars is lost so early in life in Liodontia that the minor changes in crown structure cannot be traced. However, the more important changes are clear, and that the Liodontia molar is readily derived from that of Meniscomys cannot be doubted. The lower molars of Liodontia differ from those of Meniscomys in reduction of the protoconid (which causes the fold between the protoconid and hypoconid to become more shallow), reduction in depth of lakes (so that they disappear very early in life), and reduction or loss of internal re-entrant dividing the 
talonid from trigonid. Of course, the teeth of Liodontia are much more hypsodont.

\section{EVOLUTION OF MYLAGAULID DENTITION}

The initial steps in the evolution of the Mylagaulidae were probably the same as in the Aplodontidae. As far as dental structure is concerned, Meniscomys could serve as an ancestor of both families. Judging from the structure of Promylagaulus and from its geologic
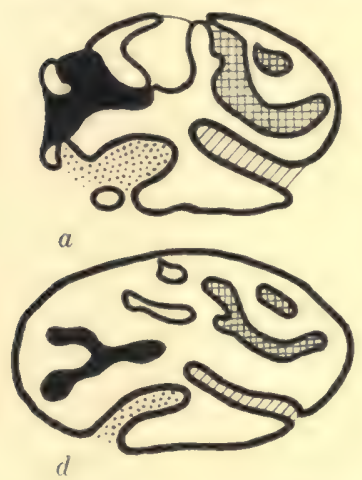
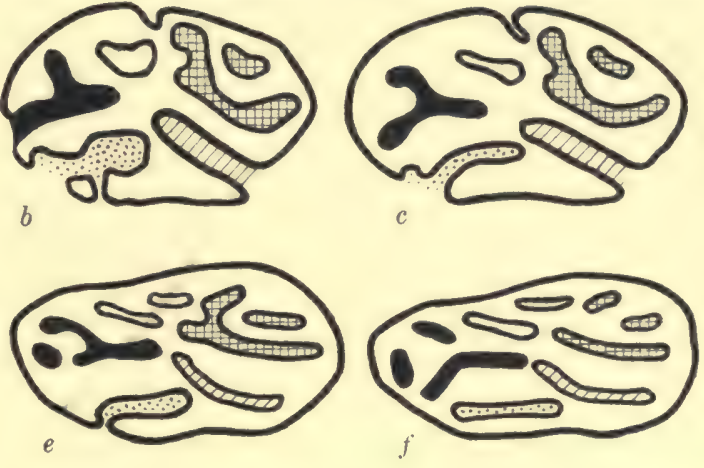

Fig. 9. Mylagaulus ef. monodon. Serial sections of $\mathrm{P}^{4}$ showing successive stages of wear. Origin of lakes in worn tooth indicated by shading.

age, it would appear that this genus originated from some member of the aplodontid stock which, if not actually Meniscomys, was a form very close to it.

$\mathrm{P}^{4}$ of Promylagaulus had advanced over that of Meniscomys primarily in attaining greater relative size, in becoming more hypsodont, and in having lost the transverse-median basin. Perhaps this latter basin is present in the unworn tooth of Promylagaulus but at least it did not deepen as the tooth increased in hypsodonty as the other basins did. The resulting pattern is one in which there are four lakes (in a worn tooth) almost certainly homologous with the antero- and postero-external and antero- and postero-internal basins of Meniscomys. The external styles of the only known specimen are rather low but this is undoubtedly due to heavy wear.

$\mathrm{P}_{\overline{4}}$ of Mylagaulodon is much larger and much more hypsodont than in Promylagaulus. In crown pattern it is much like that of the latter genus but the antero-external lake has an elongate anteroexternal projection which gives it the appearance of a horizontal Y. This extension is important as it is retained (with modification) in 

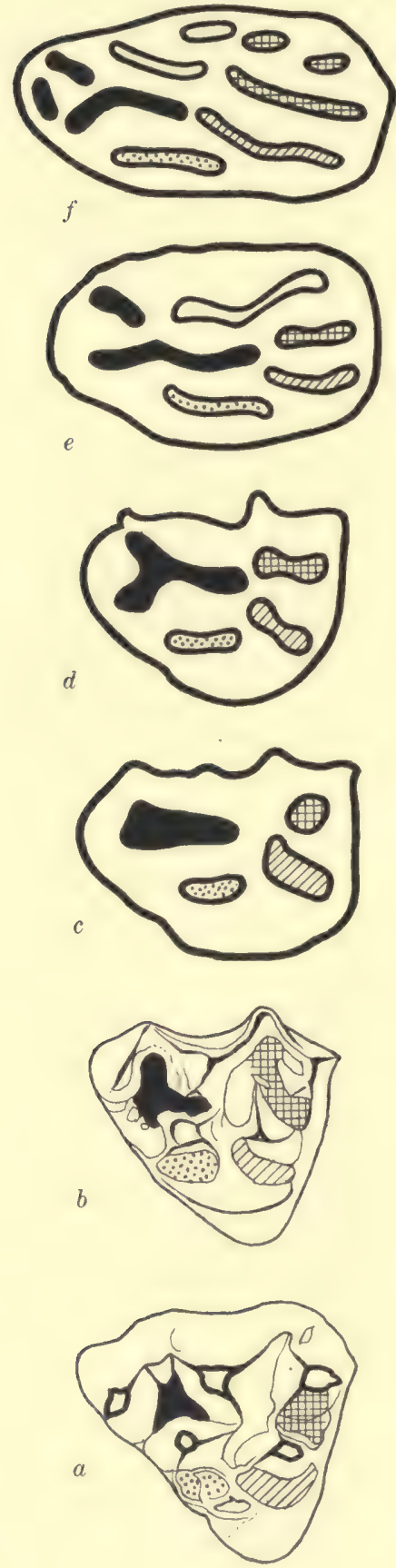

later mylagaulids. The external styles are still well developed in this genus.

The crown pattern on $\mathrm{P}^{4}$ of all the middle Miocene mylagaulids I have seen consists of six lakes, more elongate and better aligned anteroposteriorly than those of Mylagaulodon. The extension or projection of the antero-external lake is separated and has become an individual lake. The other new lake to appear is posteroexternal. I believe, judging from sections I made of Mylagaulus ef. monodon, that this lake is a portion of the original postero-external lake. This is not certain, however, as it may have originated as an invagination from the external wall of the tooth.

The Pliocene mylagaulids, as exemplified by specimens referred to $M$. monodon from Big Spring Canyon, may have as many as ten lakes in a well-worn $\mathrm{P}$ ․ If a heavily worn tooth is compared with the more primitive types it is impossible to homologize the lakes. However, by making serial sections of an unworn tooth it has been possible to determine the homologies of nearly all the lakes with considerable certainty. This is best understood by referring to figures 9 and 10 . The only point of doubt is the origin of the two small lakes (one in unworn teeth) left in white. Either they are "buds" of the antero-external lake, or they are closed invaginations from the external wall of the tooth.

FIG. 10. $\mathrm{P}^{4}$ of a, Haplomys; b, Meniscomys; c, Promylagaulus; d, Mylagaulodon; e, Mesogaulus ef. pristinus (middle Miocene); and f, Mylagaulus cf. monodon (early Pliocene). 
It is more difficult to work out the details of development of the upper molars. The crown characters are lost with relatively little wear and sufficient unworn teeth are not available. As the premolar grew disproportionately large, the molars became reduced. The first molar became progressively compressed antero-posteriorly and by mid-Miocene was present only in young individuals. By Pliocene time this tooth had become almost entirely lost. In one specimen of Mylagaulus cf. monodon from the lower Pliocene Big Spring Canyon
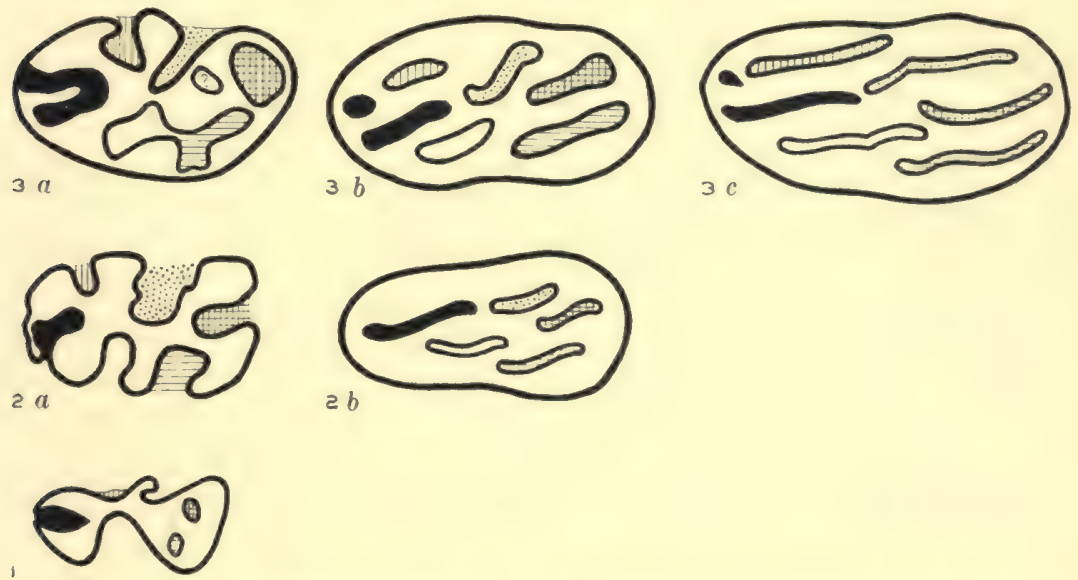

FIG. 11. $\mathrm{P}_{4}$ of 1, Meniscomys; $2 \mathrm{a}, \mathrm{b}$, Mesogaulus ef. pristinus; and $3 \mathrm{a}, \mathrm{b}, \mathrm{c}$ Mylagaulus ef. monodon, showing supposed structural development of pattern and successive stages of wear. Shading indicates homologous lakes.

(F.M. No. P15793) an $\mathrm{M}_{\mathrm{I}}$ exists, but this tooth is not present in much younger specimens from the same locality. In contrast with $\mathrm{P}$ 4, the molars apparently became progressively more simplified.

Because lower premolars of Promylagaulus or Mylagaulodon are not known it is best to discuss first the molars, which are known from the unworn teeth in nearly every stage of evolutionary development.

The referred specimen of Promylagaulus riggsi (American $\mathrm{Mu}$ seum No. 10824) differs from Meniscomys in several molar characters, all of them progressive toward Mylagaulus. The molars are much more hypsodont. The external valley between the protoconid and hypoconid has become shallow. Internally the entoconid has migrated forward to lie close to the metastylid, cutting off the internal re-entrant and producing, with slight wear, an isolated lake. Two lakes are still present in the trigonid, but in the talonid, due to the absence of the ridge running forward from the hypoconulid, 


\section{Field Museum of Natural History-Geology, Vol. 9}

the two lakes found in Meniscomys are united. However, this last character cannot be regarded as significant because the ridge between the talonid lakes is present in some specimens of Mylagaulus and absent in others belonging to the same species.

The differences between the lower molars of Promylagaulus and Mylagaulus are not great. In the latter genus they are more hypsodont and are smaller, relative to $\mathrm{P}_{\overline{4}}$. The lakes

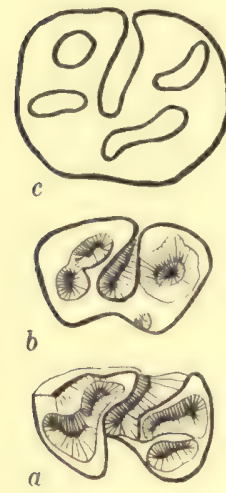

Fig. 12. $\mathrm{M}_{\mathrm{I}}$ of a, Meniscomys; b, Promylagaulus; and c, Mylagaulus. are somewhat better defined in young specimens of Mylagaulus but usually are of the same number and occupy the same relative positions as those of Promylagaulus.

Knowledge of the changes which take place in the lower molars permits a probably accurate deduction of the details in the evolution of $\mathrm{P}_{\overline{4}}$ between Meniscomys and Mylagaulus. In Meniscomys, $\mathrm{P}_{\overline{4}}$ is built on much the same plan as the molars. In the trigonid a deep re-entrant is formed between the spurs running forward from the metaconid and protoconid. Internally, between the metaconid and metastylid is a shallow valley which may be homologous with the internal lake in the molar trigonid. The external and internal re-entrants (between the talonid and trigonid) are present, as in the molars. Two lakes are again present in the talonid, as in the molars. Primitive species of Mylagaulus ${ }^{1}$ have five lakes in $\mathrm{P}_{\overline{4}}$ that are sufficiently deep to persist in worn teeth: anterior, median-external and -internal, and postero-external and -internal. The anterior one is certainly homologous with the anterior re-entrant valley of Meniscomys, the median-external with the external re-entrant, the median-internal with the internal re-entrant and the two posterior ones with the two talonid lakes of Meniscomys. In the Pliocene form, $M$. monodon, six lakes are well developed. The extra lake is formed by the deepening of the valley between the metaconid and metastylid. In addition to these six rather large lakes is a small one which splits off from the anterior one but which is apparently constant and extends deep into the crown. The lake homologies in $\mathrm{P}_{\overline{4}}$ of the mylagaulids are shown in figure 11 .

Sufficient material is not at hand to carry this study beyond the broader limits of mylagaulid development. As Wilson (1937) has

'These primitive species represent the genus Mesogaulus as defined by Cook and Gregory (1941). 
pointed out it would be particularly desirable to undertake a study of the several genera and species of the late members of the family to determine their inter-relationships and the variation within and between the taxonomic units. If, as seems likely, there is considerable uniformity within the genera and species, the complicated pattern of $\mathrm{P} \frac{4}{4}$ would facilitate such a study because differences of taxonomic importance might readily be ascertained. Because of the rapid and great change of pattern resulting from wear it will be essential to have sufficient material for making serial sections.

\section{STRATIGRAPHIC RELATIONSHIPS OF APLODONTOIDS}

It is surprising to find so many forms within the John Day representing such widely separated structural stages. This is true not only of the aplodontoid rodents but of many other mammalian groups as well. It is known that late Oligocene and early Miocene fossils occur in the John Day and it is entirely possible that Haplomys and Meniscomys are not contemporaneous but that the former is actually stratigraphically older as well as more primitive structurally. Even more surprising is the occurrence of Mylagaulodon as a possible contemporary of Meniscomys. The specimen of Mylagaulodon from the upper Rosebud is definitely later than lower Rosebud Promylagaulus, as its structure indicates it should be. It is most unfortunate that definite stratigraphic records are not available for the types from the John Day. In other regions the phylogenetic development of a group usually ties in rather well with its stratigraphic distribution. I should not be surprised if this would also be true of the John Day species if adequate data on the occurrence of the specimens were available. ${ }^{1}$

\section{ORIGIN OF THE APLODONTOIDEA}

Stock (1935) described Eohaplomys from the Sespe Eocene as an ancestor of Allomys (including Meniscomys) and Haplomys and hence of all aplodontoids. It seems reasonable that Eohaplomys did occupy such a position. Going back in time from the late Eocene there is no rodent that seems to have characters that might be considered ancestral for the group. The similarity in basic structure, however, between Prosciurus and Eohaplomys suggests that the two genera have a common ancestor. The dentition of Prosciurus

${ }^{1}$ Dr. Lewis Gazin recently has informed me that the type of Mylagaulodon angulatus was found in some local deposits lying between the true John Day and the Mascall. Hence this specimen may well be of post-John Day age. 


\section{Field Museum of Natural History-Geology, Vol. 9}

is structurally more primitive than that of Eohaplomys, particularly in the development of the paramere. I believe that the Aplodontoidea may well have originated as a branch of the Prosciurus stem, some time during the early or middle Eocene. To what ischyromyoid family Prosciurus belongs ${ }^{1}$ is unknown, as no Eocene form has been found that might be ancestral to it. There seems to have been some evidence for Matthew's regarding Prosciurus as an ancestor of the aplodontoids. However, had Eohaplomys been known at that time he would undoubtedly have altered his views accordingly.

\section{TAXONOMY}

When the pertinent phylogenetic facts are known, the problem of classifying the incipient branches of a dichotomous pattern of evolution becomes an academic matter and must be settled arbitrarily. The aim, however, should be to denote relationships as clearly as possible in a manner no more complex than the facts.

Wood's (1937) reasons for recognizing the suborder Protrogomorpha seem valid. "It seems to be impossible to include these families ${ }^{2}$ in any of the three generally accepted suborders. They are certainly not 'Histricomorphs'; they have practically nothing in common with the 'Myomorphs' and very little to do with the 'Sciuromorphs.' Neither can I see any justification for associating them with the Dipodidae. It is obvious, therefore, that they must represent an independent group, for which Zittel's term is available."

Actually there are no characters by which the Aplodontoidea may be separated from the Ischyromyoidea. Wood's statement that the cheek-tooth pattern of the Ischyromyoidea is based on transverse lophs, rather than on antero-posterior ones as in the Aplodontoidea, does not apply when the primitive members of the group are considered. Primitive aplodontoids grade imperceptibly into forms which are typically ischyromyoid in every respect. This is indicated by Stock's (1935) reference of Eohaplomys to the Ischyromyidae, although he recognized its relationships to the aplodontids.

The relationships of the aplodontoid families are known. The so-called ischyromyoids, however, are quite diversified and the inter-relationships of the families are not known. Some authors

${ }^{1}$ Since Prosciurus cannot be a descendant of any known sciuravid, its reference to that family (Wood, 1937) must remain tentative.

${ }^{2}$ Paramyidae, Sciuravidae, Ischyromyidae, Cylindrodontidae, (?)Protoptychidae, Aplodontidae, and Mylagaulidae. 
have recognized but one major group for the inclusion of all these (Winge, 1924) while others would recognize the two (Wood, 1937). The Ischyromyoidea can hardly represent a natural group, and seems to be most useful as a basket in which to throw those primitive rodents which do not give rise to later types or those whose relation-

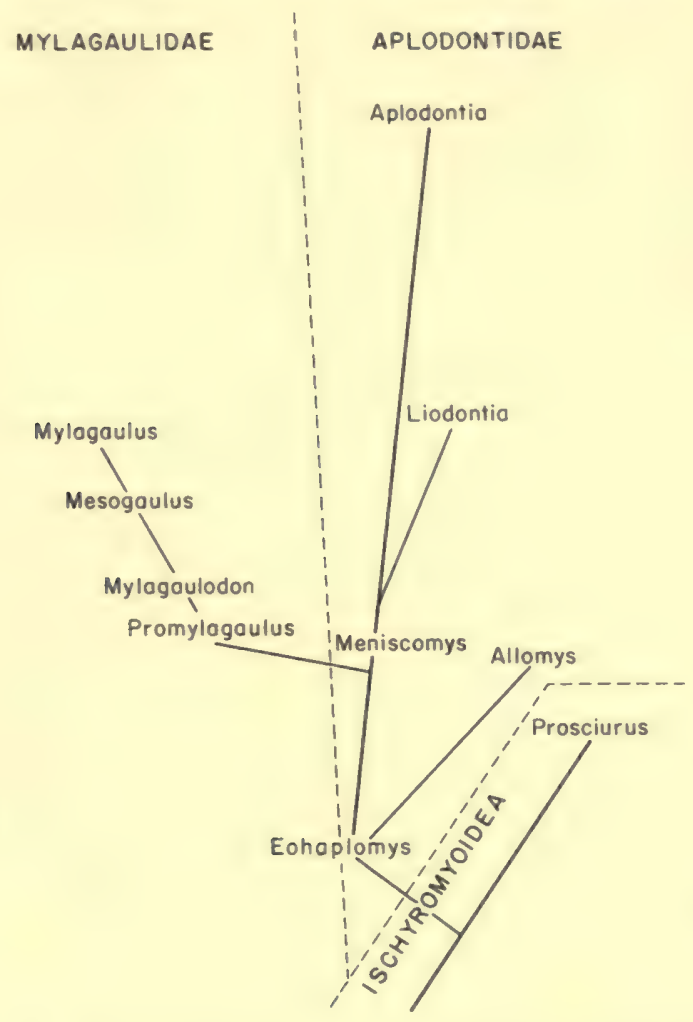

FIG. 13. Supposed relationships of the aplodontoid genera.

ships are unknown. When the early history of other rodent groups is known their primitive ancestors will undoubtedly fall within the Ischyromyoidea as diagnosed. However, when any one of those primitive forms becomes sufficiently differentiated to be recognized as an ancestor of a particular later group, it may with justification be included in the group to which it is ancestral. Thus the relationship of Eohaplomys may be best implied if the genus is classified as a primitive aplodontoid, although its characters are not such as to be distinct diagnostically from the Ischyromyoidea. 
Within the Aplodontoidea two major and at least two minor lines of descent may be recognized. The more or less direct line from Eohaplomys to Aplodontia represents the basic stock and is of family rank. A major offshoot from the Aplodontidae is represented by the series from Promylagaulus to Mylagaulus, which because of its extreme divergence and specialization also should rank as a family, the Mylagaulidae. Smaller side branches which are closely related and parallel to the parent stock are represented by Allomys and Liodontia and probably Haplomys. They are not sufficiently divergent to rate as more than aberrant genera of the family Aplodontidae.

Thus the classification of the Aplodontoidea, according to my interpretation, should be as follows:

Suborder PROTROGOMORPHA

Superfamily APLODONTOIDEA

$\begin{array}{ll}\text { APLODONTIDAE } & \text { MXLAGAULIDAE } \\ \text { Eohaplomys } & \text { Promylagaulus } \\ \text { Haplomys } & \text { Mylagaulodon } \\ \text { Allomys } & \text { Mesogaulus } \\ \text { Meniscomys } & \text { Mylagaulus } \\ \text { Liodontia } & \\ \text { Pseudaplodon } & \\ \text { Aplodontia } & \end{array}$

The relationships of these forms are best shown by the chart on page 25. It is necessary to stress the point that Mylagaulodon and Meniscomys are both from the John Day (see footnote on p. 23), and while structurally the two genera seem to bear ancestor-descendant relationships, there is a possibility that they are contemporaries.

\section{DISTRIBUTION}

The past and present distribution of the Aplodontidae is unique among mammalian families in that the range of Aplodontia, the only living member of the family and universally conceded to be the most primitive of living rodents, is limited to a small strip along the west coast of the United States. Not only is the range of the living genus thus limited, but as far as is known, every fossil form which might be ancestral to it also comes from the same general area. Such distribution cannot be explained by the principles of mammalian dispersal so ably advocated by Matthew (1915). Of Aplodontia Matthew said: "A marked exception to the rule is seen in the survival in the western Sonoran sub-region of Aplodontia, 
the most primitive living sciuromorph in several respects. I have no explanation to offer of this anomaly, save that we have not yet balanced properly the essential qualities of progressiveness among Rodentia."

For broad application Matthew's thesis can hardly be disputed, but as Dunn (1926) has pointed out, it is not complete and must be expanded to account for certain exceptions, of which Aplodontia is notable.

Mammalian evolution and migration, according to Matthew, were stimulated primarily by climatic or environmental changes. These changes appeared first in the Holarctic realm, at the center of distribution, and spread toward the temperate and tropical regions. Thus a race "should be at first most progressive at its point of original dispersal, and ... continue this progress at that point in response to whatever stimulus originally caused it and spread out in successive waves of migration, each wave a stage higher than the previous one. At any one time, therefore, the most advanced stages should be nearest the center of dispersal, the most conservative stage farthest from it." There are many exceptions, but generally the peripheral members of a group are most primitive.

There appears to have been little or no change in the distribution of Aplodontia and its ancestors since late Oligocene time; and in further contrast to the usual condition the peripheral forms, Pseudaplodon and Liodontia, are in some respects even more specialized than Aplodontia.

The aplodontids present a picture exactly the opposite of that required by the Matthewsian hypothesis. The range now occupied by Aplodontia is apparently near the center of origin and distribution of the family. This is suggested by the occurrence of Eohaplomys, Haplomys, and Meniscomys near or within the present range of Aplodontia, and at no other place. The occurrence of Pseudaplodon in the early Pliocene of Mongolia and Liodontia in the mid-Miocene of southeastern Oregon and mid-Pliocene of Nevada suggests an early unsuccessful attempt to extend the range. Of particular significance is the fact that in the limited parts known, these peripheral genera are somewhat more specialized than Aplodontia. This is indicated by the reduction of the antero-external folds (between protoconid and hypoconid) of the lower cheek teeth, which cannot be a primitive character. These dental modifications suggest migration into a different environment for which they were adaptive changes. In other words, it is most likely that these most specialized aplodontids moved into a new habitat instead of having a new 
habitat move in on them. This distribution cannot be accounted for by any climatic or environmental change at the center of dispersal.

The environmental conditions along the west coast might have been quite stable during Tertiary time, at least sufficiently so that the aplodontids were able to maintain their range with relatively little structural modification. Those that migrated did so either because of population pressure or the inherent tendency of all animal life to expand. They were not successful in adapting themselves to new habitats, either because of harder environmental conditions or because of unsuccessful competition with better adapted forms. This apparently resulted in extinction of marginal forms and re-constriction of the family range to the original dispersal center.

The history of the Mylagaulidae, on the other hand, differs greatly. It appears that immediately after its inception the family spread to the Great Plains. In late Miocene and early Pliocene times its members are found in nearly every well-known fauna of the United States. This sudden expansion was probably due to the loss of some inhibiting factor, either structural or physiological, a change that permitted the group to occupy a much more extensive range than did the family from which it arose.

The above discussion is of necessity based largely on negative evidence, particularly the absence of ancestral aplodontids in regions outside the far west. I believe, however, that the faunae of the plains are sufficiently well known to warrant such a hypothesis.

\begin{tabular}{|c|c|c|c|}
\hline \multicolumn{4}{|c|}{$\begin{array}{l}\text { MEASUREMENTS } \\
\text { (In millimeters) }\end{array}$} \\
\hline $\begin{array}{l}\text { Allomys } \\
\text { cavatus }\end{array}$ & $\begin{array}{c}\text { Meniscomys } \\
\text { hippodus }\end{array}$ & $\underset{\text { Progsi }}{\text { Promylagaulus }}$ & $\begin{array}{l}\text { Mylagaulodon } \\
\text { cf. angulatus }\end{array}$ \\
\hline$\underset{6988}{\text { A.M. No. }}$ & A.M. No. & $\begin{array}{l}\text { F.M. No. } \\
\text { P26255 }\end{array}$ & $\begin{array}{l}\text { F.M. No. } \\
\text { P26266 }\end{array}$ \\
\hline $\mathrm{P}^{4} \mathrm{a}-\mathrm{p} \ldots \ldots \ldots 2.84$ & 2.66 & 3.41 & 5.89 \\
\hline $\mathrm{P}=\operatorname{tr} \ldots \ldots \ldots \ldots 2.80$ & 2.43 & 2.60 & 4.40 \\
\hline $\mathrm{M}^{1} \mathrm{a}-\mathrm{p} \ldots \ldots \ldots 2.15$ & 2.10 & 1.54 & \\
\hline $\mathrm{M}^{1} \operatorname{tr} \ldots \ldots \ldots 2.80$ & 2.35 & 2.25 & \\
\hline $\mathrm{M}^{2} \mathrm{a}-\mathrm{p} \ldots \ldots \ldots 2.10$ & 2.10 & 1.84 & \\
\hline$M^{2}$ tr $\ldots \ldots \ldots 2.75$ & 1.92 & 1.91 & \\
\hline$M^{3}$ a-p...... 2.10 & 2.10 & 1.30 & \\
\hline $\mathrm{M}^{3} \operatorname{tr} \ldots \ldots \ldots 2.47$ & 1.76 & 1.52 & \\
\hline$\underset{6988}{\text { A.M. No. }}$ & $\underset{6964}{\text { A.M. No. }}$ & $\begin{array}{l}\text { A.M. No. } \\
10824\end{array}$ & \\
\hline$\ldots \ldots 3.45$ & 3.45 & & \\
\hline $\mathrm{P}_{4}$ tr....... 2.31 & 2.31 & & \\
\hline $\mathrm{M}_{\mathrm{I}} \mathrm{a}-\mathrm{p} \ldots \ldots 2.19$ & 2.05 & 2.38 & \\
\hline $\mathrm{M}_{\mathrm{T}} \operatorname{tr} \ldots \ldots \ldots 1.61$ & 1.93 & 1.87 & \\
\hline $\mathrm{M}_{\overline{2}} \mathrm{a}-\mathrm{p} \ldots \ldots 2.11$ & 2.78 & 2.00 & \\
\hline$M_{\overline{2}} \operatorname{tr} \ldots$ & 1.95 & 1.77 & \\
\hline $\mathrm{M}_{\overline{3}} \mathrm{a}-\mathrm{p} \ldots \ldots 2.41$ & 2.40 & 2.40 & \\
\hline$M_{3} \operatorname{tr} \ldots \ldots \ldots 1.68$ & 1.76 & 1.25 & \\
\hline
\end{tabular}




\section{REFERENCES}

Cook, H. J. and Gregory, J. T.

1941. Mesogaulus praecursor, a New Rodent from the Miocene of Nebraska. Jour. Pal., 15, pp. 549-552, figs. 1, 2.

Cope, E. D.

1878. Descriptions of New Extinct Vertebrata from the Upper Tertiary and Dakota Formations. Bull. U. S. Geol. and Geog. Surv. Territories, 4, pp. 379-396.

1879. On Some Characters of the Miocene Fauna of Oregon. Proc. Amer. Phil. Soc., 18, pp. 63-78.

1881. Review of the Rodentia of the Miocene Period of North America. Bull. U. S. Geol. and Geog. Surv. Terr., 6, pp. 361-386.

1883. The Extinct Rodentia of North America. Amer. Nat., 17, pp. 43-57, figs. 1-13.

1884. The Vertebrata of the Tertiary Formations of the West. Rept. U. S. Geol. Surv. Terr., 3, pp. 1-xxxv, 1-1009, pls. 1-75a.

DuNn, E. R.

1926. The Salamanders of the Family Plethodontidae. Smith College 50th Anniv. Pub., pp. 1-441.

Friant, M.

1937. Le pretendu genre Pseudaplodon de Gerrit S. Miller (Aplodontia asiatica Schlosser) au pontien de Mongolie. Ann. Mag. Nat. Hist., 19, pp. 456-462, figs. 1-11.

FURLONG, E.

1910. An Aplodont Rodent from the Tertiary of Nevada. Univ. Calif. Pub., Bull. Dept. Geol., 3, pp. 397-403, figs. 1-6.

GAZIN, L.

1932. A New Miocene Mammalian Fauna from Southeastern Oregon. Carnegie Inst. Wash., Contr. Pal., 418, pp. 39-86, figs. 1-20, pls. 1-6.

GidLEY, J. W.

1907. A New Horned Rodent from the Miocene of Kansas. Proc. U. S. Nat. Mus., 32, pp. 627-636, pls. 58-65.

HILL, J. E.

1935. The Cranial Foramina in Rodents. Jour. Mamm., 16, pp. 121-129, figs. 1-3.

MARSH, O. C.

1877. Notice of Some New Vertebrate Fossils. Amer. Jour. Sci., 15, pp. 249 256, 1 fig.

Matthew, W. D.

1901. Fossil Mammals of the Tertiary of Northwestern Colorado. Mem. Amer. Mus. Nat. Hist., 1, pt. 7, pp. 355-447, figs. 1-34, pl. 39.

1902. A Horned Rodent from the Colorado Miocene. With a Revision of the Mylagauli, Beavers, and Hares of the American Tertiary. Bull. Amer. Mus. Nat. Hist., 16, pp. 291-310, figs. 1-17.

1904. New or Little Known Mammals from the Miocene of South Dakota. Bull. Amer. Mus. Nat. Hist., 20, pt. 2, pp. 246-265, figs. 1-13.

1910. On the Osteology and Relationships of Paramys and the Affinities of the Ischyromyidae. Bull. Amer. Mus. Nat. Hist., 28, pp. 43-71, figs. 1-18. 


\section{Field Museum of Natural History-Geology, Vol. 9}

1915. Climate and Evolution. Ann. N. Y. Acad. Sci., 24, pp. 171-318, figs. $1-33$.

1924. Third Contribution to the Snake Creek Fauna. Bull. Amer. Mus. Nat. Hist., 50, pp. 59-210, figs. 1-63.

MERRIAM, J. C.

1916. Tertiary Vertebrate Fauna from the Cedar Mountain Region of Western Nevada. Univ. Calif. Pub., Bull. Dept. Geol., 9, pp. 161-198, figs. 1-48, pl. 8.

Miller, G. S.

1927. Revised Determinations of Some Tertiary Mammals from Mongolia. Palaeontologia Sinica, ser. C, 5, fasc. 2, pp. 1-20.

and Gidley, J. W.

1918. Synopsis of the Supergeneric Groups of Rodents. Jour. Wash. Acad. Sci., 8, pp. 431-448.

RIGGS, E. S.

1899. The Mylagaulidae: An Extinct Family of Sciuromorph Rodents. Field Columbian Mus., Geol. Ser., 1, pp. 181-187, 2 figs.

\section{SCHLOSSER, M.}

1924. Tertiary Vertebrates from Mongolia. Palaeontologia Sinica, ser. C, 1, fasc. 1 , pp. 1-119, figs. $1-5$, pls. 1-6.

SinClaIR, W. S.

1903. Mylagaulodon, A New Rodent from the Upper John Day of Oregon. Amer. Jour. Sci., 15, pp. 143-144, fig. 1.

STOCK, C.

1935. New Genus of Rodent from the Sespe Eocene. Bull. Geol. Soc. Amer., 46, pp. 61-68, fig. 1, pl. 6 .

WILsON, R. W.

1937. New Middle Pliocene Rodent and Lagomorph Faunas from Oregon and California. Carnegie Inst. Wash., Contr. Pal., Pub. 487, pp. 1-19, pls. 1-3.

1937a. Pliocene Rodents of Western North America. Carnegie Inst. Wash., Contr. Pal., Pub. 487, pp. 21-73, figs. 1-2.

WINGE, H.

1924. Pattedyr-slaegter. Part II. Rodentia, Carnivora, Primates. Publ. Univ. Zool. Mus. Copenhagen, Nr. 31, pp. 1-321, figs.

WooD, A. E.

1937. The Mammalian Fauna of the White River Oligocene. Part II. Rodentia. Trans. Amer. Phil. Soc., 28, pp. 155-269, figs. 8-70, pls. 23-33. 

THE LIBRARY OF THE

DEC 181941

UNIVERSITY OF ILLINOIS 






UNIVERSITY OF ILLINOIS-URBANA

$550.5 F$

FIELDIANA, GEOLOGY CHGO

7-9 1937/45

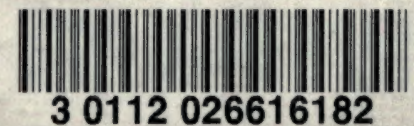

